\title{
Analisis Pendapatan dan Kelayakan Hasil Usahatani Padi Sawah di Desa Mrentul Kecamatan Bonorowo Kabupaten Kebumen
}

\author{
Rahmat Joko Nugroho ${ }^{\text {a }}$, Indra Nur Ramadhan ${ }^{\mathrm{b}}$ \\ ${ }^{a, b}$ Program Studi Agroteknologi, Universitas Ma'arif Nahdlatul Ulama Kebumen \\ rahmatjokon@gmail.com ${ }^{\text {a }}, \underline{\text { Indraramadhan873@gmail.com }}{ }^{\text {b }}$
}

\begin{abstract}
Abstrak
Desa Mrentul merupakan salah satu Desa di Kecamatan Bonorowo Kabupaten Kebumen yang memiliki luas lahan sawah paling luas diantara Desa-Desa lain di Kecamatan Bonorowo. Luasnya lahan dan besarnya jumlah produksi padi sawah di Desa Mrentul tidak cukup menjamin pendapatan yang diperoleh petani juga tinggi.Oleh sebab itu diperlukan suatu penelitian yang menganalisis pendapatan dan kelayakan usahatani padi sawah di Desa Mrentul. Penelitian ini bertujuan untuk mengetahui besarnya pendapatan dan kelayakan usahatani padi sawah yang dilaksanakan pada bulan Mei hingga bulan Agustus 2020. Penentuan lokasi dilakukan secara sengaja ( purposive) dengan pertimbangan bahwa Desa Mrentul merupakan daerah penghasil padi sawah paling tinggi di Kecamatan Bonorowo dibanding dengan desa-desa lainnya, dengan produktivitas sebesar 2,9 ton/ha.Penentuan responden dilakukan dengan metode sampel acak sederhana ( Simple Random Sampling ). Sampel yang diambil sebanyak 30 responden KK petani dari 419 KK petani yang mengusahakan padi sawah.Analisis yang digunakan pada penelitian ini adalah analisis pendapatan $(\pi)$ dan kelayakan.Hasil analisis menunjukkan bahwa rata-rata pendapatan petani padi sawah untuk satu kali musim tanam di Desa Mrentul Kecamatan Bonorowo Kabupaten Kebumen sebesar Rp 4.093.048/Ha.Hasil analisis menunjukkan Revenue Cost Ratio usahatani padi sawah sebesar 1,4 atau R/C > 1.Dengan demikian, usahatani padi sawah di Desa Mrentul layak untuk diusahakan.
\end{abstract}

Kata kunci: Pendapatan, Padi Sawah, Kelayakan

Abstract
Mrentul village is one of village those are on Bonorowo district that have largest
rice field than the other village in Bonorowo district. Largest field and outgrows $f$
rice in Mrentul village that acquired haven't secured height income that accepted
by the farmers. The research needed to aim and analyze income and expedience
farming of rice pant in Mrentul village and was conducted at May until August
2020. The location was done bay purposive which consideration that Mrentul
village is one of highest production area with productivity 2,9 ton/ha. Respondent
determination to be done by simple random sampling method (Simple Random
sampling). Sample was took as many as 30 KK respondent of farmer from $419 \mathrm{KK}$
farmers. The analysis that used in this research is analysis income ( $\pi$ ) and
expedience (a). The result of analysis showed that average income rice plant of
farmers to once inplant at Mrentul village Bonorowo district Kebumen regency


about $R p$ 4.093.048/ha. Result of analysis show revenue rice field farm obtained equal to 1,4 or $R / C>1$ thereby rice filed farm in Mrentul village competent to be labored.

\section{Key word: Earning,Ekspedience, Rice Field}

\section{Pendahuluan}

Indonesia adalah negara agraris dimana sebagian besar penduduknya bermata pencaharian bercocok tanam.Secara geografis Indonesia yang juga merupakan negara kepulauan memiliki potensi sumber daya alam yang besar, tak hanya dalam bidang kelautan, tetapi juga dalam bidang pertanian. Sektor pertanian merupakan ujung tombak bagi bangsa Indonesia untuk mewujudkan tercapainya pembangunan nasional dalam mencukupi kebutuhan pangan. Keberhasilan di sektor ini diharapkan dapat menjamin ketahanan pangan yang berakar pada keberagaman sumber bahan pangan, kelembagaan dan budaya local ( Kartasapoetra, 1998).

Pengembangan tanaman pangan merupakan salah satu bagian dari sector pertanian yang mendapat perhatian serius dan terus dikembangkan hingga saat ini. Tujuan pembangunan pangan adalah untuk mewujudkan kondisi terpenuhinya kebutuhan pangan dengan gizi yang cukup bagus penduduk untuk menjalani hidup sehat dan produktif, dengan pertambahan jumlah penduduk dan perubahan selera makan, maka ketersediaan harus ditingkatkan , baik dalam jumlah, kualitas maupun keragamannya. (Adiratma, 2004).

Pertanian Indonesia merupakan pertanian tropika yang artinya sebagian besar atau seluruh daerah pertanian di Indonesia merupakan daerah tropis dan langsung dipengaruhi oleh garis khatulistiwa,yang memotong Indonesia hamir menjadi dua ,salah satu komoditas tanaman pangan di Indonesia adalah padi yang hasil produksinya masih jadi sumber bahan makanan pokok.Padi merupakan tanaman pertanian dan merupakan tanaman utama dunia (Fatmawati M, 2013)

Padi merupakan tanaman yang menghasilkan beras. Bahan makanan ini merupakan bahan makanan pokok bagi sebagian besar penduduknya. Meskipun padi dapat diganti oleh makanan lain, namun padi memiliki nilai tersendiri bagi orang yang biasa makan nasi dan tidak dapat dengan mudah diganti oleh makanan lain (Siregar, $2001: 16$ ).

Komoditas pertanian khususnya padi sawah dapat dikategorikan sebagai komoditi komersial karena sebagian besar ditujukan untuk memenuhi kebutuhan pasar dengan harga yang berlaku di pasar..

Beras bukan hanya sebagai komoditi pangan dan ekonomis, tetapi juga sebagai komoditas politik dan keamanan. Beras sebagai makanan pokok tetap mendominasi pola makan orang Indonesia. Hal ini terlihat dari tingkat partisipasi konsumsi beras yang tinggi yaitu 95 persen. Ketergantungan terhadap beras ini mengakibatkan permintaan terhadap beras semakin tinggi,Kebijakan yang ditempuh pemerintah untuk mewujudkan tujuan pembangunan nasional diantaranya adalah dengan peningkatan peningkatan kehidupan ekonomi yang dilakukan melalui pembangunan pertanian.

Meskipun permintaan beras semakin meningkat dari tahun ketahun ,akan tetapi di sisi lain sebagian petani khususnya padi merupakan masyarakat dengan pendapatan tergolong rendah, rata-rata pendapatan rumah tangga petani masih rendah yakni hanya sekitar $30 \%$ dari 
Universitas Ma'arif Nahdlatul Ulama Kebumen total pendapatan keluarga. Sealain berhadapan dengan rendahnya pendapatan yang diterima para petani, sector pertanian juga dihadapkan pada penurunan produksi dan produktivitas hasil pertanian,hal ini berkaitan erat dengan sulitnya meningkatkan produktivitas padi di lahan-lahan yang sudah terlalu lama diberi inputan pupuk degan konsentrasi tinggi tanpa mempertimbangkan status kesuburan tanah lahan dan pemberian pupuk organik (Moettaqien. 2012)

Kebijakan ekonomi bertujuan untuk menciptakan kemakmuran bagi rakyat dan salah satu faktor terpentingnya adalah pendapatan. Pendapatan regional adalah tingkat besarnya pendapatan pada wilayah analisis. Tingkat pendapatan dapat diukur dari total pendapatan wilayahmaupun pendapatan rata-rata masyarakat pada wilayah tersebut. Petani sebagai makhluk social juga pasti berharap mempunyai taraf hidup yang sesuai dalam hidupnya ,peningkatan taraf hidup tersebut diperoleh dengan cara meningkatkan pendapatannya. Untuk memperoleh pendapatan yang tinggi dilaksanakan berbagai kegiatan dengan mengembangkan kemungkinan komoditi pertanian lain (diversifikasi usahatani) yang secara ekonomis bisa menguntungkan jika lahan pertaniannya memungkinkan (tarigan, 2005).

Alternatif yang diperlukan untuk mememcahkan masalah tersebut adalah memacu peningkatan produktivitas usahatani padi dan peningkatan pendapatan petani,penggunaan input haruslah efisien,khusunya pada lahan irigasi dan non irigasi supaya tidak mengurangi pendaptan petani,efisiensi penggunaan faktor-faktor produksi juga bertujuan untuk meningkatkan hasil pendapatan serta sebagai bentuk ikut serta dalam usaha pelestarian lingkungan.

Kebumen adalah sebua Kabupaten yang berada di bagian selatan jawa tengah. Secara geografis, Kabupaten Kebumen terletak pada $7^{\circ} 27^{\prime}-7^{\circ} \mathrm{g} 0^{\prime}$ Lintang Selatan dan $109^{\circ} 33^{\prime}$ $109^{\circ} \mathrm{g} 0^{\prime}$ Bujur Timur. Bagian selatan Kabupaten Kebumen merupakan dataran rendah, sedangkan pada bagian utara berupa pegunungan dan perbukitan yang merupakan bagian dari rangkaian Pegunungsn Serayu Selatan Sementara itu di barat wilayah Giombong, terdapat Kawasan Karst Gombong selatan sebuah rangkaian pegunungan kapur yang membujur hingga pantai selatan berarah utara-selatan yang sebagian besar merupakan pantai dengan fenomena gumuk pasir. Sungai terbesar di Kabupaten Kebumen adalah Sungai Luk Ulo, Sungai Jatinegara, Sungai Karanganyar, Sungai Kretek, Sungai Kedungbener, Sungai Kemit, Sungai Gombong, Sungai Ijo, Sungai Kejawang, dan Kali Medono.

Kabupaten Kebumen mempunyai luas wilayah sebesar 158.111, 50 ha atau 1.581, $11 \mathrm{~km}^{2}$, dari luas wilaya6 tersebut tercatat Luas tanam di Kebumen pada Oktober 2019-Agustus 2020 mencapai 73.984 hektare. Sedangkan luas panen 51.319 hektare, dengan produktivitas 55 kwintal per hektare gabah kering giling (GKG). Produksi mencapai 282.260 ton GKG. Adapun kebutuhannya beras penduduk Kabupaten Kebumen per tahun sebesar 134.017,05 ton. Sedangkan ketersediaan beras 257.546,45 ton, sehingga terjadi surplus sebesar 123.529,4 ton beras.( Distapang Kebumen, 2020). Pramono dkk, (2005) berpendapat hasil pertanian agoekosistem masih bervariasi. Rata-rata 4,7 ton / hektar dengan potensi $6-7$ ton /ha

Setiap tahunnya luas lahan pertania di Desa mrentul selalu mengalami perbahan yang juga mempengeruhi jumlah produksi padi.sejalan dengan perubahan tersebut maka pendapatan petani akan turut berubah, semakin besar jumlah produksi semakin besar pula pendapatan yang diterima. Begitu pula sebaliknya, apabila produksi menurun maka pendapatan yang diterima akan semakin kecil. 
Universitas Ma'arif Nahdlatul Ulama Kebumen

Potensi yang ada untuk mengembangkan padi sawah masih dirasa cukup menjanjikan mengingat ketersediaan luas lahan yang cukup luas khususnya di Kecamatan Bonorowo salah satunya di Desa Mrentul. Selain itu masyarakat di Desa Mrentul sudah mulai mengenal dan menggunakan teknologi yang cukup memadai. Pendapatan petani didukung oleh tingkat kelayakan usaha tani yang baik melalui besarnya rasio penerimaan terhadap biaya usaha tani. Rasio yang tinggi diharapkan mampu menaikkan tingkat pendapatan petani padi sawah di suatu daerah. Oleh sebab itu untuk mengetahui secara jelasnya permasalahan ini maka diperlukan adanya suatu penelitian mengenai pendapatan dan kelayakan usahatani padi sawah di Desa Mrentul Kecamatan Bonorowo Kabupaten Kebumen

\section{Rumusan Masalah}

1. Berapa besar pendapatan usahatani padi sawah di Desa Mrentul Kecamatan Bonorowo Kabupaten Kebumen.

2. Apakah usahatani padi sawah di Desa Mrentul Kecamatan Bonorowo Kabupaten Kebumen layak untuk diusahakan

\section{Tujuan Penelitian}

Tujuan penelitian ini adalah untuk mengetahui :

1. Pendapatan usahatani padi sawah di Desa Mrentul Kecamatan Bonorowo Kabupaten Kebumen

2. Kelayakan usahatani padi sawah di Desa Mrentul Kecamatan Bonorowo Kabupaten Kebumen

\section{Manfaat Penelitian}

Manfaat yang bisa diperoleh dari penelitian ini adalah sebagai berikut :

1. Bahan informasi bagi petani dalam usahatani padi sawah dalam upaya meningkatkan pendapatan agar memperoleh kelayakan usaha

2. Bahan pertimbangan literatur untuk peneliti selanjutnya

\section{Metodologi Penelitian}

Penelitian dilaksanakan di Desa Mrentul Kecamatan Bonorowo Kabupaten Kebumen. Lokasi penelitian ini dipilih secara sengaja (purposive) dengan mempertimbangkan bahwa, Desa Mrentul merupakan daerah dengan luas lahan sawah yang paling luas dari Desa-Desa lain di Kecamatan Bonorowo selain itu mayoritas masyarakatnya bermata pencaharian sebagai petani terutama padi sawah, sehingga penerimaan pendapatan terbesar diperoleh dari hasil usahatani. Penelitian ini dilaksanakan pada bulan mei hingga bulan agustus 2020.

Berdasarkan karakteristik petani di Desa Mrentul terdapat 419 petani yang mengusahakan usahatani padi sawah.Menurut Suharyadi (2008), setiap petani memiliki kesempatan yang sama untuk terpilih menjadi sampel karena populasi penelitian tergolong mendekati homogen. Untuk itu pengambilan sampel untuk penelitian ini dilakukan dengan cara sampel acak sederhana ( simple random sampling ). Adapun jumlah sampel yang diambil dalam penelitian ini adalah 30 orang. Menurut Sugiono ( 2003 ) berpendapat bahwa sampel minimum dalam penelitian adalah 30 responden. 
Universitas Ma'arif Nahdlatul Ulama Kebumen

Metode yang digunakan dalam penelitian ini adalah metode survei yaitu peneliti melakukan pengamatan atau penyelidikan langsung ke lapangan untuk mengetahui permasalahan yang diteliti melaui daftar pertanyaan (Singarimbun dan Effendi, 2009)

Data yang digunakan dalam penelitian ini bersumber dari data primer dan sekunder. Pengumpulan data primer dilakukan dengan cara observasi, dan wawancara langsung dengan menggunakan daftar pertanyaan (Quiseonere), sedang data sekunder diperolrh dari berbagai sumber yakni berbagai instansi yang berkaitan dengan penelitian ini serta berbagai literatur

Penelitian ini menggunakan dua analisis data yaitu:

\section{Analisis pendapatan}

Soekartawi (1995) menyatakan pendapatan usahatani adalah selisih antara penerimaan ( TR) dan semua biaya (TC), dimana penerimaan usaha tani adalah perkalian anatara produksi dan harga jual, sedangkan biaya adalah semua pengeluaran yang digunakan dalam suatu usahatani. Jadi rumus pendapatan dapat dituliskan sebagai berikut :

$$
\pi=\mathbf{T R}-\mathbf{T C}
$$

Keterangan:

$\pi \quad=$ Pendapatan

TR = Total Revenue ( Total Penerimaan)

TC $=$ Total Cost ( Total Biaya)

Dimana : $\mathbf{T R}=\mathbf{P} . \mathbf{Q}$

$$
\mathbf{T C}=\mathbf{F C}+\mathrm{VC}
$$

\section{Analisis Kelayakan}

Kelayakan usahatani adalah suatu ukuran untuk mengetahui usaha ini layak untuk diusahakan atau tidak layak. Dalam hal ini berarti dapat menghasilkan suatu manfaat atau tidak. Suatu usahatani yang akan dilaksanakan dinilai dapat memberikan keuntungan atau layak diterima jika dilakukan analisis kelayaka usaha, kelayakan usaha dapat diketahui dengan pendekatan R/C. R/C adalah singkatan dari revenue cost ratio atau dikenal dengan perbandingan antara total peerimaan $(\mathrm{R})$ dan total biaya $(\mathrm{C})$

Soekartawi (1995) lebih lanjut mengemukakan bahwa analisis revenue cost ratio merupakan analisis yang melihat perbandingan antara penerimaan dan pengeluaran. Tujuannya adalah untuk mengetahui layak atau tidak usahatani itu dilaksanakan,dengan rumus:

$$
\mathbf{a}=\frac{\mathrm{R}}{\mathrm{C}}
$$

Keterangan : 


$$
\begin{array}{ll}
\text { a } & \text { Universitas Ma'arif Nahdlatul Ulama Kebumen } \\
\mathrm{R} & =\text { Total Revenue } \\
\mathrm{C} & =\text { Total cost }
\end{array}
$$

Apabila $\mathrm{R} / \mathrm{C}=1$, berarti usahatani tidak untung tidak pula rugi atau impas, selanjutnya bila $\mathrm{R} / \mathrm{C}$ $<1$, menunjukkan bahwa usaha tersebut tidak layak diusahakan, dan jika R/C > 1 maka usahatani tersebut layak untuk diusahakan (Soekartawi, 2002).

\section{Hasil Dan Pembahasan}

Desa Mrentul merupakan salah satu Desa di Kecamatan Bonorowo yang bisa ditempuh dengan jalur darat sekitar $20 \mathrm{~km}$ dari Ibu Kota Kabupaten Kebumen. Secara administratif Desa Mrentul terdiri dari tiga wilayah pedukuhan. Paling barat Pedukuhan Saragan dengan jumlah 7 RT dan 1 RW,Pedukuhan Karang Tengah dengan 6 RT, dan pedukuhan Mrentul dengan 8 RT , untuk RW pedukuhan Karang Tengah dan Mrentul digabung menjadi satu dengan urutan RW 01 untuk wilayah Mrentul, dan RW 02 untuk wilayah karang tengah

Analisis pendapatan dalam penelitian ini ditujukan untuk mengetahui besarnya pendapatan petani responden pada usahatani padi di Desa Mrentul selama satu kali musim panen ,dengan cara menghitung selisih antara total penerimaan dan total biaya yang dikeluarkan dalam satu silkus pembudidayaan

Penerimaan dalam penelitian ini merupakan hasil perkalian antara jumlah produksi yang diperoleh dengan harga jual ditingkat petani .berdasarkan hasil penelitian, rata-rata produksi padi sawah yang diperoleh petami responden selama satu kali musim panen adalah $1.600 \mathrm{Kg}$ dikalikan dengan harga jual di tingkat petani sebesar Rp 5000/Kg sehingga dihasilkan rata-rata penerimaan yang diperoleh petani responden adalah sebesar Rp 8.000.000 / $0.55 \mathrm{Ha}$ atau Rp $11.545 .500 / \mathrm{Ha}$

Dalam setiap kegiatan usahatani, seorang petani akan dihadapkan pada masalah beban biaya yang harus dikeluarkan untuk menghasilkan produksi. Adapun biaya dibedakan menjadi dua, yaitu biaya tetap ( fixed cost ) dan biaya variable ( variable cost )

Biaya tetap adalah biaya yang relative jumlahnya meski produksi yang diperoleh banyak ataupun sedikit ,dengan kata lain biaya tetap tidak bergantung pada besar kecilnya jumlah produksi yang didapat. Dalam penelitian ini, biaya tetap yang dikeluarkan oleh petani terdiri dari biaya pajak dan penyusutan alat. Berdasarkan pada data penelitian yang telah diolah, diperoleh rata-rata biaya tetap yang dikeluarkan oleh petani responden adalah sebesar Rp 1.339.778/0,55 Ha atau sebesar Rp 2.435.959/Ha

Biaya variable adalah biaya yang besar kecilnya dipengaruhi oleh produksi yang dihasilkan. Biaya variable yang dikeluarkan oleh petani responden dalam penelitian ini adalah biaya benih, pupuk, dan tenaga kerja. Berdasarkan data penelitin yang telah diolah diperoleh rata-rata biata variable yang dikeluarkan oleh petani responden di Desa Mrentul adalah sebesar Rp 4.409.071 / 0.55 ha atau sebesar Rp 8.016.493 / Ha

\subsection{Pendapatan Usahatani}


Universitas Ma'arif Nahdlatul Ulama Kebumen

Analisis pendapatan dalam penelitian ini digunakan untuk mengetahui besarnya pendapatan yang diperoleh petani responden usahatani padi sawah di Desa Mrentul dengan cara menghitung selisih antara total penerimaan dengan total biaya yang dikeluarkan maka perlu dikehui dulu besarnya tingkat penerimaan yang diperoleh serta biaya-biaya yang dikeluarkan dahulu besarnya tingkat penerimaan yang diperleh serta biaya-biaya yag dikeluarkan dalam melakukan usahatani tersebut

Untuk lebih jelasnya dapat dilihat pada Tabel 1 berikut ini :

Tabel 1 menunjukkan bahwa rata-rata luas lahan 0,55 ha rata-rata produksi $1600 \mathrm{Kg} / \mathrm{Ha}$ atau setara dengan konversi $2.909 .10 \mathrm{Kg} / \mathrm{Ha}$ dan harga jual $\mathrm{Rp} 5.000$, jadi rata-rata penerimaan petani sebesar Rp 8.000.000/0.55 Ha atau sebsar Rp 14.545.500/ Ha. Sedang rata-rata biaya tetap sebesar Rp 1.339.778 /0,55 Ha atau sebesar Rp 2.435.959 / Ha dan total biaya variabel Rp 4.409.071/0,55 Ha atau sebesar Rp 8.016.493/ Ha. Jadi rata-rata biaya total produksi sebesar Rp $5.748 .849 / 0,55 \mathrm{Ha}$ atau sebesar Rp10.452.452/Ha. Tabel 1 menunjukkan bahwa rata-rata setelah dilakukan penjumlahan antara rata-rata biaya total dan rata-rata biaya penerimaan, dapat diketahui bahwa rata-rata pendapatan yang diperoleh petani adalah sebesar $\mathrm{Rp} 2.251 .151 / 0,55$ ha atau sebesar Rp 4.093.048/Ha. Hal ini menunjukkan bahwa petani di Desa Mrentul telah menghasilkan pendapatan dari kegiatan usahataninya.

Tabel 1 : Rata-rata Aktual (0,55 Ha) dan Konversi/1 Ha Penerimaan, Total Biaya dan Pendapatan Petani Responden Padi Sawah Desa Mrentul.

\begin{tabular}{|c|c|c|c|}
\hline No & Uraian & $\begin{array}{c}\text { Nilai Aktual } \\
\text { ( Rp/0,55 ) }\end{array}$ & $\begin{array}{c}\text { Nilai Konversi } \\
(\mathbf{R p} / \mathbf{H a})\end{array}$ \\
\hline 1 & Penerimaan Usahatani & & \\
\hline & - $\quad$ Rata-rata Produksi (Kg) & 1.600 & 2909,10 \\
\hline & - $\quad$ Harga Jual (Rp/Kg) & 5.000 & 5000 \\
\hline & Rata-rata Penerimaan & 8.000 .000 & 14.545 .500 \\
\hline 2 & Biaya Produksi & & \\
\hline & 1. Total Biaya Tetap & 1.339 .778 & 2.435 .959 \\
\hline & a. Pajak Lahan & 16.741 & 30.438 \\
\hline & b. Penyusutan Alat & 111.437 & 202.612 \\
\hline & c. Sewa Lahan & 658.000 & 1.196 .364 \\
\hline & d. Sewa Traktor & 553.600 & 1.006 .545 \\
\hline & 2. Total Biaya Variabel & 4.409 .071 & 8.016 .493 \\
\hline & a. Tenaga Kerja & 3.429 .320 & 6.235 .127 \\
\hline & b. Benih & 221.600 & 402.909 \\
\hline & c. Pupuk & 541.713 & 984.933 \\
\hline & d. Pestisida & 216.438 & 393.524 \\
\hline
\end{tabular}




\begin{tabular}{rrr}
\hline Rata-rata Biaya Total & 5.748 .849 & 10.452 .452 \\
Rata-rata Pendapatan & 2.251 .151 & 4.093 .048 \\
\hline
\end{tabular}

Sumber ; Hasil Analisa Data Primer, ( 2020 )

\subsection{Analisis Kelayakan Usahatani Padi Sawah}

Untuk dapat mengetahui kelayakan pengembangan usahatani padi sawah digunakan analisis Revenue of Cost Ratio (R/C), dengan rumus sebagai berikut :

$$
\mathrm{a}=\frac{R}{C}
$$

Keterangan :

a $\quad=$ Perbandingan antara Total revenue dengan Total Cost

$\mathrm{R}=$ (Total Revenue) penerimaan total, dinyatakan dalam satuan $(\mathrm{Rp})$

$\mathrm{C}=($ Total Cost $)$ biaya total,dinyatakan dalam satuan $(\mathrm{Rp})$

Dengan kriteria apabila

$\mathrm{R} / \mathrm{C}>1$ = Usahatani padi sawah menguntungkan atau layak diusahakan

$\mathrm{R} / \mathrm{C}=1$ = Usahatani padi sawah berada pada titik impas

$\mathrm{R} / \mathrm{C}<1$ = Usahatani padi sawah rugi atau tidak layak diusahakan

Berdasarkan hasil penelitian diperoleh tingkat kelayakan usahatani padi sawah sebagai berikut $\mathrm{a}=\frac{R}{C}$

$$
\begin{aligned}
& =\frac{8.000 .000}{5.748 .849} \\
& =1,4
\end{aligned}
$$

Penerimaan yang diterima oleh petani responden adalah Rp 8.000.000 dengan rata-rata biaya total sebesar Rp 5.748.849, sehingga diperoleh Revenue of Cost Ratio sebesar 1,4. Dengan demikian usahatani padi sawah di Desa Mrentul layak untuk diusahakan sebab nilai rasi R/C > 1. Menurut Nurmalina et al. (2009) menyatakan bahwa suatu usaha tidak akan ditolak oleh masyarakat sekitarapabila dari aspek sosial budaya diterima dan secara ekonomi memberikan kesejahteraan.

\section{Kesimpulan}

Hasil analisis pendapatan menunjukkan bahwa rata-rata pendapatan petani padi sawah untuk satu kali musim tanam di Desa Mrentul Kecamatan Bonorowo Kabupaten Kebumen sebesar Rp 4.093.048/Ha. Hasil analisis menunjukkan Revenue of Cost Ratio usahatani padi sawah sebesar 1,4. Dengan demikian usahatani padi sawah di Desa Mrentul layak untuk diusahakan, sebab R/C > 1 .

\section{Daftar Pustaka}


Adiratma, 2004. Tanaman Padi. Penebar Swadaya. Jakarta.

Universitas Ma'arif Nahdlatul Ulama Kebumen

Badan Pusat Statistik, 2020. Bonorowo Dalam Angka 2020.BPS

Kartasapoetra, 1998. Pengantar Ekonomi Produksi Pertanian. Bina Aksara. Jakarta.

M, Fatmawati. 2013. Analisis Pendapatan Petani Padi Di Desa Teep Kecamatan Lawongan Timur. Jurnal Penelitian Vol.1 No.3 September 2013.

Moettaqien. 2012. Analisis Pendapatan Petani Miskin Dan Implikasi Kebijakan Pengentasannya. Skripsi. Di Kecamatan Perbaugen, Kabupaten Serdang Bedagai, Tesis Magister Sains. Sekolah Pasca Sarjana. Universitas Sumatra Utara.Medan.

Nurmalina, R., Sarianti, T. dan Karyadi, A. 2009. Studi Kelayakan Bisnis. Bogor: Departemen Agribisnis Fakultas Ekonomi dan Manajemen InstitutPertanian Bogor.

Pramono, Joko, S. Basuki dan Widarto. 2005. Upaya Peningkatan Produktivitas Padi Sawah Melalui Pendekatan Pengelolaan Tanaman Terpadu dan Sumberdaya Terpadu. Jurnal Agrosains. Vol. 7 No. 1 Tahun 2005.

Soekartawi, 2003. Ekonomi Pertanian. Universitas Indonesia, Press. Jakarta.

Soekartawi, 2002. Teori Ekonomi Produksi. PT. Raja Grafindo Persada, Jakarta.

Singarimbun, Masri dan S. Effendi. 2009. Metode Penelitian Survei. LP3ES. Jakarta.

Siregar, H. 1981. Budidaya Tanaman Padi di Indonesia. Sastra Hudaya. Jakarta.

Soekartawi. 1986. Ilmu Usahatani dan Penelitian Untuk Pengembangan Petani Kecil. UI-Press. Jakarta.

Sugiyono, 2003. Metode Penelitian Bisnis. CV. Alvabeta. Bandung.

Suharyadi dan Purwanto. 2008. Statistika Untuk Ekonomi Dan Keuangan. Modern Edisi 2 Buku 1. Jakarta: Salemba empat

Tarigan, Robinson, 2005. Ekonomi Regional Teori dan Aplikasi. Edisi Revisi. Jakarta : Bumi Aksara

Suratiyah, 2008. Ilmu Usahatani. PT. Penebar Swadaya. Jakarta. 